Original Research Paper

\title{
Bawean Island Citizens' Perception and Attitude toward the Existence of Bawean Deer (Axis kuhlii) and Its Habitat
}

\author{
Miarsono Sigit \\ Faculty of Veterinary Medicine, University of Wijaya Kusuma Surabaya, Surabaya, Indonesia
}

\section{Article history}

Received: 02-08-2019

Revised: 16-11-2019

Accepted: 27-11-2019

Email: miarsonosigit2@gmail.com

\begin{abstract}
Bawean deer (Axis kuhlii) is an Indonesian endemic - animal species that is categorized as Critically Endangered by IUCN and listed on Appendices I by CITES. This study aims to analyse Bawean citizens' perceptions and attitude to forest and the Bawean deer. The study was conducted by direct interviews and field observations. The respondents were determined by purposive sampling and quota sampling resulted in 191 respondents. The result indicates that the Bawean citizens have a low education level. Some of them finished education after elementary school (39.89\%) and have not even completed this level $41.49 \%$. Most of the Bawean citizens work as farmers $(62.23 \%)$ and rely on the forest for their livelihoods, such as hunting for fresh meat. It is concluded that the educational background and well-being level of the Bawean citizens influence the perception of Bawean deer and wildlife reserve forest. Further, it will affect the existence and sustainability of the forest ecosystem. The citizens' attitudes towards the environment will be favourable if they have a high education level and forest supervision is held continuously.
\end{abstract}

Keywords: Attitude, Bawean Citizens', Bawean Deer, Perception, Wildlife Reverse

\section{Introduction}

Bawean Island locates at $\pm 150 \mathrm{Km}$ from Gresik city to the north Java Sea and geographically lies on $5^{\circ} .42^{\prime \prime}$ to $5^{\circ} .53^{\prime \prime}$ North Latitude (NT) dan $112^{\circ} .34^{\prime \prime}$ to $112^{\circ} .36^{\prime \prime}$ East Longitude (EL). Bawean Island administratively belongs to level II regional autonomy of Gresik government, East Java province. The area is subdivided into two districts that are Sangkapura district at the southern area that consists of 17 villages and Tambak district at the north that consists of 13 villages. From those 30 villages, 20 of them lie close to or even adjoin forest conservation area. In Sangkapura district, there are 13 villages located near the forest area, while Tambak district provides 7. The topography of Bawean Island, generally, is hilly with altitudes of 300 to $600 \mathrm{~m}$ ASL. Its slope may go $5 \%$ up to $75 \%$ and its area extends over 19,742 ac (acres) consisting of 5,316 ac of rice field, 10,419 ac of dry land and paddy field, also 4.538 ac of forest conservation area consisting 3.183 ac wildlife reserve and 725 ac of sanctuary (Elmaleh et al., 2007).

Forest conservation areas in Bawean Island are the Bawean deer's primary habitat (Rahman et al., 2016). The Bawean deer is an Indonesian endemic deer species that has the narrowest and minimal populating distribution area, which occurs only in Bawean Island, Gresik, East Java. The Bawean deer's population in the primary habitat are minimal in numbers, ranging about 300-400. Therefore, Bawean deer are listed into crisis or very endangered category by CITES as appendix 1 and International Union for Conservation of Natural Resources (IUCN) (Semiadi et al., 2008). Further, the Bawean deers is a critically endangered species (Rahman et al., 2017a).

The Bawean deer population has declined and became endangered. A function shifting of the forest and the turn of tropical forest into the teak forest that decreases the bushes population causes the decline of Bawean deer's population. As a result, natural food supplies for Bawean deer decrease (Prevedello et al., 2013), which is followed by the increase of the parasite infection of these animals (Nurcahyo, 2015). Further, the massive number of illegal hunting and logging by local citizens becomes the primary factor (Rahman et al., 2017a).

The decline of the Bawean deer population triggers the effort to preserve the Bawean deer from extinction by establishing the wildlife reserve. The aims are to maintain existence of Bawean deer and increase the population. It is necessary to analyse the Bawean 
citizen's perception of the wildlife reserve and Bawean deer's entity.

\section{Materials and Methods}

\section{Ethical Clearance}

This study has been approved and following the federal guideline of the local committee of University of Wijaya Kusuma Surabaya. The study was conducted from January 2018 until January 2019.

\section{Locations}

The research locations are villages that lie near forests which are suspected as the Bawean deer's habitat. The several areas that are used as the sampling location were Pudakit Barat, Pudakit Timur, Suari, Kumalasa, Teluk Jati Dawang, Grejeg dan Paromaan.

\section{Data Collection}

The study was conducted using survey methods. It involved a direct interview and field observation on locals to understand regarding their perception of wildfire reserve and Bawean deer. The respondent is determined using purposive and quota sampling, the ways to determine sample that utilizes particular characteristics until the targeted number.

The number of samples is determined using a formula as the follow:

Sample size $=\frac{\lambda^{2} \cdot N \cdot P \cdot Q}{d^{2} \cdot(N-1)+\lambda^{2} \cdot P \cdot Q}$
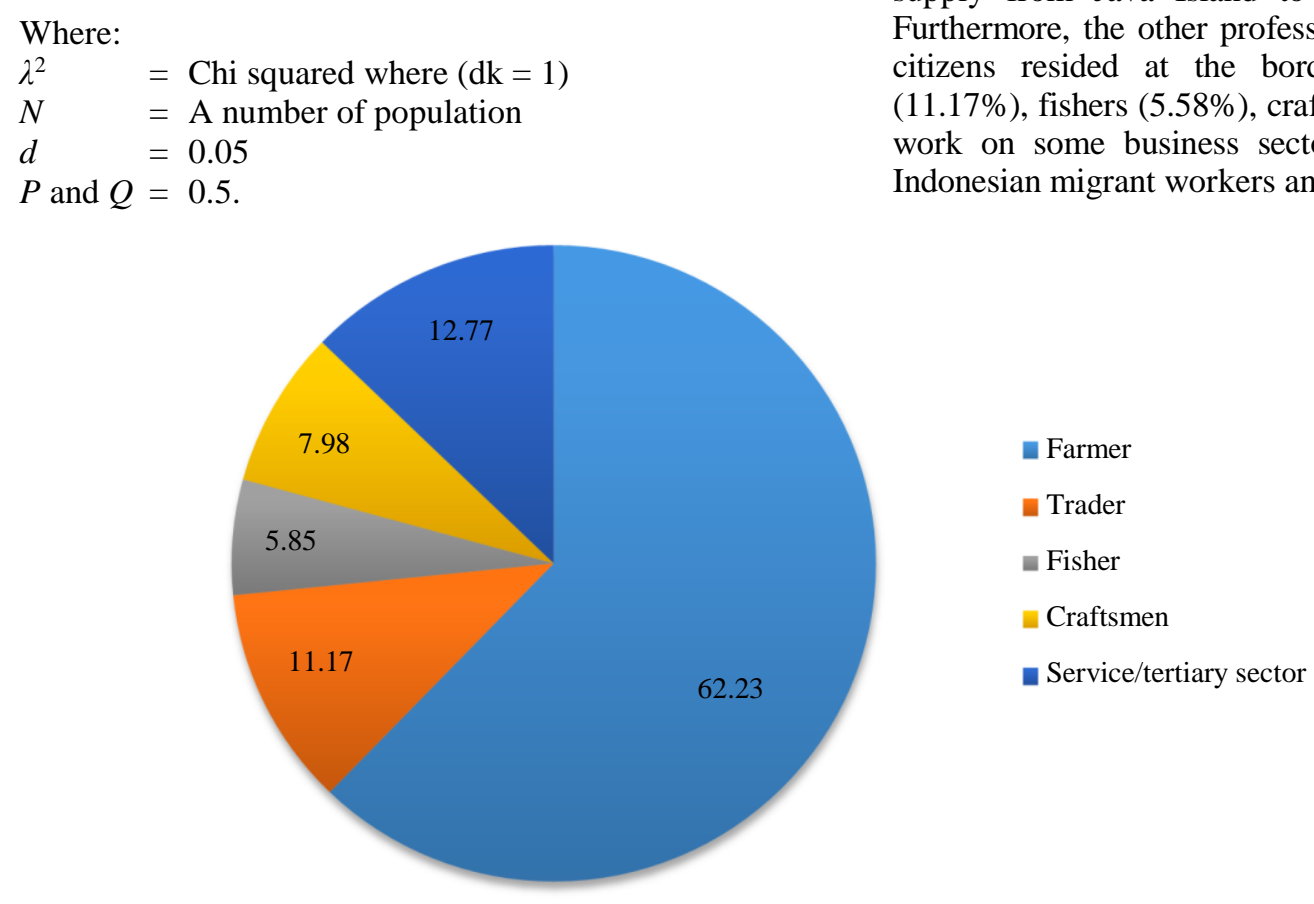

Fig. 1: The Bawean citizens' occupations
The formula was used to determining the number of a sample from citizens/head of households who were chosen and resided at Bawean forest border. Factually, there were 650 heads of household. The probability of miscalculation was $10 \%$. So then, the formula's outcome resulted in 191 citizens as the sample.

\section{Questionnaire}

The Bawean citizens' were interviewed and provided the questionnaire. Several questions on the questionnaire include the social economy of the local citizens (employment, monthly income, educational status); the perception of the local citizens regarding the Bawean deer existence (Bawean deer as hunted animal, its protection, mascot, livestock, availability as the individual or institutional reserve); and the perception of local citizens on wildlife reserve in Bawean Island.

\section{Data analysis}

Further, the data were tabulated as the primary data and it analyzed by correspondence test and Chi-square using SPSS 21 . The probability value was $5 \%$.

\section{Results}

\section{Citizens' Social Economy Condition}

Most of the citizens of Bawean Island work as farmers $(62.33 \%)$. The rice farming, which is operated by the local citizens is more self-family supply purpose. On the other hand, the local citizens still rely on the rice supply from Java Island to suffice the rice demand. Furthermore, the other professions practised by the local citizens resided at the border of forest are traders (11.17\%), fishers (5.58\%), craftsmen (7.89\%) and the rest work on some business sector such as tertiary sector, Indonesian migrant workers and labors (12.77\%) (Fig. 1). 


\section{Perception of Bawean Deer Existence}

The result showed that most of the local citizens disagreed on using Bawean deer as a hunted animal $(84.82 \%)$. A further result showed that preponderance of the Bawean citizens (94.24\%) impressive if the deer is utilised as a mascot of Bawean Island. On the other hands, nine respondents $(4.71 \%)$ were absent to give a response on this issue. The significant number of the citizens agreed $(82.20 \%)$ to utilise the Bawean deer as livestock just like goats or sheep on F2 descendants. Some disagreement expressed in about $15.18 \%$ of the total respondents. The disagreed respondent revealed that it was complicated. Moreover, the deer must have individually or institutionally preservation feed for a longterm program (Table 1).

\section{Citizens' Perception of Wildlife Reserve Forest}

According to the interview results, the respondents generally supplied positive manners. The agreed respondents provide a positive assessment to maintain and manage wildlife reserve area, including its flora and fauna. The further analysis reflected that a total of $65.97 \%$ wood consumption is used by the local citizens and the rest for sale (Table 2). There were $9.95 \%$ of respondents claimed that they enter to the wildlife reserve area for hunting the wild hogs that damaged their farm. However, forest police declared that the locals enter the forest not for hog hunting because all of them were Muslim that prohibited to consuming wild hogs. The locals commonly enter the forest for hunting the deer and perform some illegal logging, especially at night. Because of some locals illegal activity, a total of $76.96 \%$ of Bawean citizens reject the forest police to access the forest for supervision. On the other hands, the agreed respondents (12.57\%) with a high school background realised about the forest function on the global ecosystem, including the forest police supervision system. Further, the rest $(10.47 \%)$ had no idea on this issue (Table 3). The minimum educational background influences the local citizen's mindset on forest restoration. It was proved by the result that indicated a total of $61.26 \%$ agree to join the force for restoration; however, the total of $10.47 \%$ would like to join it if there is any reward (Table 3 ).

\section{Bawean Forest Border Citizens' Attitude on Bawean Deer and Wildlife Reserve}

The $84.82 \%$ of the Bawean citizens give a positive attitude to the existence of Bawean deer and wildlife reserve. Some of the citizens showed a negative attitude $(22.52 \%)$ such as restriction access for the police to enter the forest. Because of the forest police's activities affects the local income that utilises the forest as a hunting ground and illegal logging. The $5.23 \%$ of neutral respondents declared that they never found Bawean deer inside the forest. A majority, the citizens' attitude on the forest is positive $(69.63 \%)$ because they had had brief and lecture from the Natural Resource Conservation Agency (NRCA) and some related agencies (Table 4). There is a correlation between Bawean citizen's attitude on Bawean deers and wildlife reserve at $p-$ value $=0.00$ $(p<0.05)$ in both of parameters (Table 4$)$.

Table 1: The citizens' perception of Bawean deer

\begin{tabular}{|c|c|c|c|c|c|c|c|}
\hline \multirow[b]{3}{*}{ Num. } & \multirow[b]{3}{*}{ Parameters } & \multicolumn{6}{|c|}{ Response } \\
\hline & & \multicolumn{2}{|l|}{ Agree } & \multicolumn{2}{|c|}{ Disagree } & \multicolumn{2}{|c|}{ Absent (Undecided) } \\
\hline & & Num. & $\%$ & Num. & $\%$ & Num. & $\%$ \\
\hline$\overline{1}$ & Bawean deer are available as hunted animal & 11 & 5.76 & 162 & 84.82 & 18 & 9.42 \\
\hline 2 & Bawean deer need to be protected & 174 & 91.10 & 4 & 2.09 & 13 & 6.81 \\
\hline 3 & Bawean deer become a mascot of Bawean Island & 180 & 94.24 & 2 & 1.05 & 9 & 4.71 \\
\hline 4 & Bawean deer are available for livestocking & 157 & 82.20 & 29 & 15.18 & 5 & 2.62 \\
\hline 5 & Bawean deer are available to individual or instutional reserve & 136 & 71.20 & 48 & 25.13 & 7 & 3.67 \\
\hline
\end{tabular}

$(\%)=$ percentages of respondent responses regarding the questionnaire.

Table 2: The citizens' attitude of entering wildlife reserve area

\begin{tabular}{|c|c|c|c|}
\hline \multirow[b]{2}{*}{ Num. } & \multicolumn{3}{|l|}{ Purpose to enter the forest } \\
\hline & Activities & Number & $\%$ \\
\hline 1 & Catching Bird & 3 & 1.57 \\
\hline 2 & Hunting deer & 3 & 1.57 \\
\hline 3 & Hunting wild hog & 19 & 9.95 \\
\hline 4 & Collecting firewood & 126 & 65.97 \\
\hline 5 & Collecting honey & 12 & 6.28 \\
\hline 6 & Collecting medicinal plants & 11 & 5.76 \\
\hline 7 & Collecting grass & 12 & 6.28 \\
\hline \multirow[t]{2}{*}{8} & Collecting fruit & 5 & 2.62 \\
\hline & Total & 191 & 100.00 \\
\hline
\end{tabular}

$(\%)=$ percentages of respondent responses regarding the questionnaire 


\begin{tabular}{|c|c|c|c|c|c|c|c|}
\hline \multirow[b]{3}{*}{ Num. } & \multirow[b]{3}{*}{ Parameters } & \multicolumn{6}{|c|}{ Response } \\
\hline & & \multicolumn{2}{|l|}{ Agree } & \multicolumn{2}{|c|}{ Disagree } & \multicolumn{2}{|c|}{ Absent (Undecided) } \\
\hline & & Num. & $\%$ & Num. & $\%$ & Num. & $\%$ \\
\hline 1 & Forest can freshen surrounding Environment & 176 & 92.15 & 4 & 2.09 & 11 & 5.76 \\
\hline 2 & Forest can prevent landslide and flood & 176 & 92.15 & 4 & 2.09 & 11 & 5.76 \\
\hline 3 & Forest can retain water supply & 176 & 92.15 & 4 & 2.09 & 11 & 5.76 \\
\hline 4 & Animals or plants in forests cannot be taken Without Permission & 163 & 85.34 & 15 & 7.85 & 13 & 6.81 \\
\hline 5 & wildlife reserve Forest supervised by forest police routinely & 24 & 12.57 & 147 & 76.96 & 20 & 10.47 \\
\hline 6 & The citizens involved to restore if forest damaged & 117 & 61.26 & 54 & 28.27 & 20 & 10.47 \\
\hline 7 & Setting fences for wildlife reserve Border & 140 & 73.30 & 15 & 7.85 & 36 & 18.85 \\
\hline 8 & Rebuke / report to authorities if anyone damaged forest found & 144 & 75.39 & 44 & 23.04 & 3 & 1.57 \\
\hline 9 & Protection of forest against fire & 174 & 91.10 & 0 & 0.00 & 17 & 8.90 \\
\hline 10 & Entering wildlife reserve with permission & 28 & 14.66 & 151 & 79.06 & 12 & 6.28 \\
\hline 11 & Counseling about function of forest and wild animal for the citizens & 148 & 77.49 & 38 & 19.89 & 5 & 2.62 \\
\hline
\end{tabular}

$(\%)=$ percentages of respondent responses regarding the questionnaire.

Table 4: The forest border citizens' behaviour on Bawean deer and wildlife reserve in Bawean Island

\begin{tabular}{|c|c|c|c|c|c|c|c|c|}
\hline \multirow[b]{3}{*}{ Num. } & \multirow[b]{3}{*}{ Parameters } & \multicolumn{6}{|c|}{ Response } & \multirow[b]{3}{*}{$P$-value } \\
\hline & & \multicolumn{2}{|c|}{ Positive } & \multicolumn{2}{|c|}{ Negative } & \multicolumn{2}{|c|}{ Absent (Undecided) } & \\
\hline & & Num. & $\%$ & Num. & $\%$ & Num. & $\%$ & \\
\hline 1 & Bawean deer preservation & 162 & 84.82 & 19 & 9.95 & 10 & 5.23 & $0.00 *$ \\
\hline \multirow[t]{2}{*}{2} & Forest reserve & 133 & 69.63 & 43 & 22.52 & 15 & 7.85 & $0.00 *$ \\
\hline & Total & 295 & 77.23 & 62 & 16.25 & 25 & 6.54 & - \\
\hline
\end{tabular}

$(\%)=$ percentages of respondent responses regarding the questionnaire.

\section{Discussion}

\section{Citizens' Social Economy Condition}

Based on the conservative view, the Bawean citizens are categorized as the poor. Those professions provide monthly income ranging from $520 \mathrm{~K}$ IDR up to $1,045 \mathrm{~K}$ IDR. The locals generate more meagre income if it is compared to the Monthly Region Minimum Wage of Gresik Region that is set on 2,195K IDR per month. It shows that the local's monthly income is less than $50 \%$ of average citizens' income compared to the regional and Indonesian standard. It leads the locals to have secondary employment to cover daily needs.

The local citizens are unable to provide higher formal education level for the children because of the low income. Besides, some of the children are requested to helping the parents work, such as work on rice farming, fishing, livestock shepherd, while some of them are employed as hired farmworkers or working on landlords' farm. The ones that are financially sufficient enough and have relatives abroad as Indonesian migrant workers will entrust their children to join the migrant worker force. They migrate to neighbouring countries like Malaysia, Singapore, Taiwan, or other Asian countries. On the formal education sector, border forest citizens in Bawean Island are categorized as low education level society, as the following Fig. 2.

\section{Perception of Bawean Deer Existence}

Society's attitude and opinion-forming are impacted by the perception and knowledge about something they practice. Moreover, it impacts on the human interaction type and personality, such as environmentally friendly or unfriendly (Sorqvist, 2016). The human with environmentally friendly personality will behave positively to the forest and ecosystem, while the others refuse to the environmental movement and conduct nature exploitation (Kennedy et al., 2015). In this case, there are two opinions regarding Bawean deer's existence. The first, if Bawean citizens assume the Bawean deers as a pest, people will hunt and kill them (Byrd et al., 2017) and the second if people consider that Bawean deers are the germplasm it will change the people's attitude to protect them under the law and will not conduct the illegal hunting.

The citizens hardly or even never found the deer wandering around the local's farm anymore. It makes some of the local citizens assume that Bawean deer is endangered and must be preserved. The NRCA and the Civil Society Organization (CSO) performs continuous counselling to forms the environmentally friendly personality of Bawean citizens. The counselling addressed to the citizens to increase the environment public awareness, protect the Bawean deers and its habitats and introduce the environmental conservation 
law and its punishments. Several incidents prove those policies are useful, for example, local citizens began to place the captured deers on the conservation area in Bawean Island.

On the other hands, the agreed citizens to making Bawean deer as hunted animals come from old generations and migrants hunters (Rode-Margono et al., 2019). Further, some of the local traditions in the eastern of Bawean Island such as animal hunting for Ied Mubarak celebration day also responsible for a decrease of Bawean deers population. However, that tradition was gradually prohibited by the conservation law especially the prohibition of local citizens to entering wildlife reserve forest (Bobo et al., 2015).

The majority of Bawean citizen agreed to use Bawean deers as a mascot. It because of the mascot increase value of Bawean Island as a tourism destination which is also the endemic deer's habitat that can be claimed both national and internationally. Rahman et al. (2017b) stated that the endemic deer's habitat could be used to attract tourist and increase the value of the protected forest. The agreed respondents declared that protection could reduce the risk of Bawean deers from illegal hunting and extinction. The disagreed respondents considered that preservation cost is expensive and diminished the deer's occurrence in the forest (Semiadi et al., 2003). Those illustrations proved that the locals with mid-high education level realise the importance of conservation and conservation law that protect the ecosystem inside (Bedural, 2018).

\section{Citizens' Perception of Wildlife Reserve Forest}

The economic problems of the locals cause high interaction between people with the forest, primarily to collect the wood supply. The Bawean citizens highly utilise forest wood as a woodfire and as a source of livelihood. Bawean citizens routinely enter the forest from two until three times a week, that impacts on the Bawean deers food supply and existence. Because of the high activity of Bawean citizens enter the forest causes the Bawean deers to migrate in the centre of the jungle, which has a minimum food supply. Those findings potentially impact on the degradation of Bawean forest area, including the decrease of springs and waterabsorbing area. Illegal logging causes damage of wildlife habitat in the forest, not only for Bawean deers but also the other wild animals and humans (Rahman et al., 2017b). As the endemic species, Bawean deers are listed on the endangered status and protected by wild animal protection law (Doonan et al., 2009). However, the minimum awareness of the locals inhibits the growing population of these species. So, it is necessary to solve the problems.

The limitation of forest police personnel also impacts forest preservation in Bawean Island. In the Bawean Island, there is only four forest police to guard the Bawean wildlife reserve that consists of two civil servants and two volunteers. It causes the minimum access to protect the forest from illegal logging and hunting. In 2012, the chief of NRCA had prohibited the forest border citizens from entering wildlife reserve forest. Entering forest is disallowed by any purpose, including collecting grass for livestock. It impacts on the citizens' income since their life relies on the forest. Bawean citizens understood the role and function of forest trough electronic media (television); however, the Bawean citizens still cutting wood from the forest because of their economic problems.

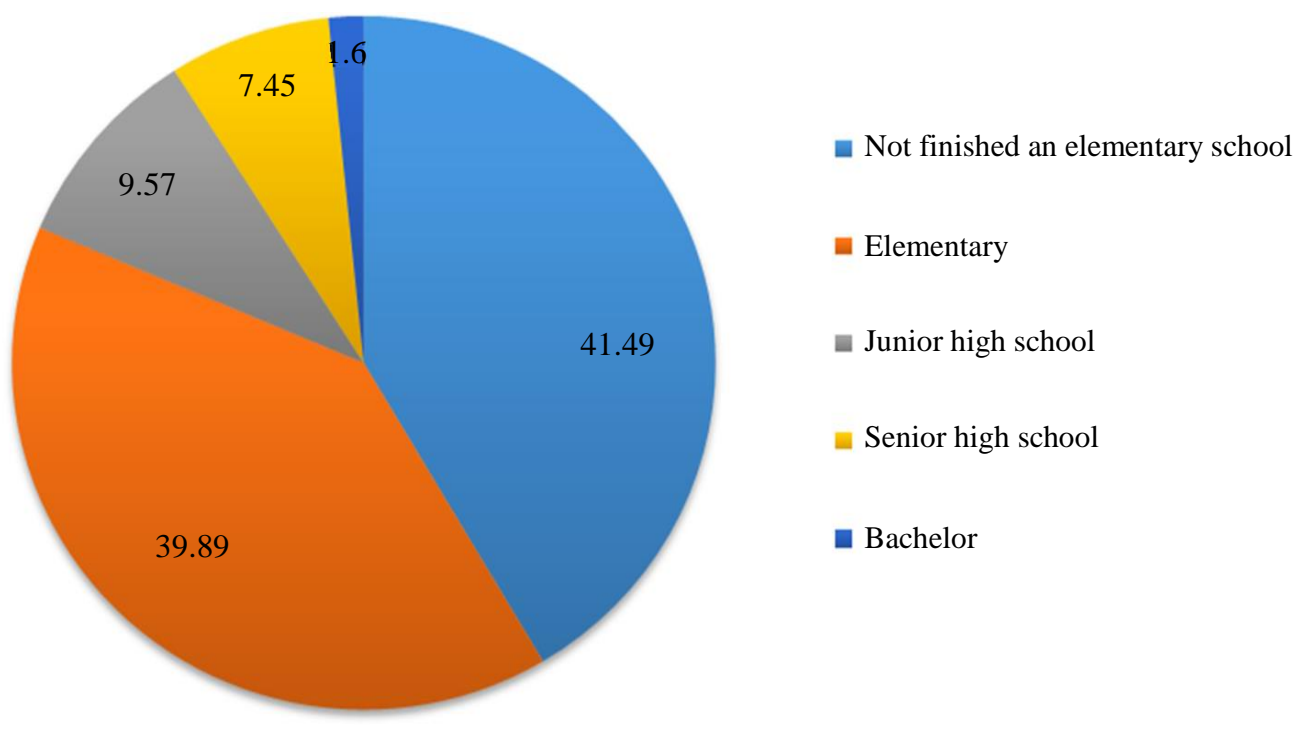

Fig. 2: The Bawean citizens' education level 
The locals assumed that forests belong to the government so the government budget should cover any issue related to it. Further, the illegal logging commonly conducted by the woman citizens because the man migrates to the other Asian counties as Indonesian workers. The citizens entirely accepted the idea of establishing a fence for forest border because it will be useful to line the border of the local's farm from the wild hogs at night. The counselling must be performed by the authorised officers to increase Bawean citizens awareness. Further, the protection of forest and the citizens' farmland that adjoins wildlife reserve should be delivered as well to decrease human-wild animals conflicts (Symes et al., 2018).

The forest destruction is synergistic with the citizen's knowledge, understanding and educational levels regarding forest role and functions in human life. Those were directly or indirectly contributes to environmental damage in Bawean Island. Besides, the government must conduct more intensive and sustainably counselling to build social awareness and conservation laws understanding. Lack of government counselling impacts the ignorant attitude of locals to rehabilitate the critical lands surrounding the area of the villages. The Bawean citizens were unrealising that this negative attitude (do not preserve land and illegal logging) potentially impacts on the wood supply in Bawean Island (Barlow et al., 2014; Rademaker et al., 2016).

\section{Bawean Forest Border Citizens' Attitude on Bawean Deer and Wildlife Reserve}

Most of Bawean citizens showed a positive attitude on Bawean deers existence $(84.82 \%), p=0.00(p<0.05)$ (Table 4). Some of the reasons are no one of Bawean deers were identified wandering the local's farm and mid-high education level transfers the experiences on the mid-low education level regarding Bawean deers extinction. Based on those reasons, the local citizens necessary to protect the Bawean deers for their existence in the endemic habitat. Those situations were realised when researches of Bawean deer were growing and electronic medias instalment reached to villages in Bawean Island. For example, if a Bawean deer enter into village area after being chased by a wild dog, it will be caught and trusted it to conservation agency instead killing it for (Saito and Koike, 2013).

The negative attitude was shown by some of the citizens that like to hunt and still run the tradition in the holiday, especially Ied Mubarak. In that day, the locals are hunting the wild forest animals to provide meat demand and consumption. It was aggravating because of beef and lamb are not available in the local market. The neutral respondents $(5.23 \%)$ did not make any decision regarding this issue because some of them never seen Bawean deer in nature. It proved that the educational status influence on attitude and environmental knowledge (Lieflander and Bogner, 2018).

The brief counselling from the NRCA generates Bawean citizen's positive attitude on forest preservation $(69.63 \%), p<0.00(p<0.05)$ (Table 4). Based on the counselling, the locals realise that the forest is a prominent part of human life, including springs, wood supply and food supply. The locals understand that forest preservation will increase and normalise forest function and production. A total of $22.25 \%$ of respondents showed a negative attitude because they have limited access to the forest that causes minimum income (Table 4). The prohibition of forest access impacts the farm destruction caused by a wild hog. It is aggravated because of the farm was standing on the fenceless area. The neutral citizens have a piece of limited knowledge and low education that influence on their environmental awareness.

\section{Conclusion}

This study described that low education and wellbeing level impact on the citizens' perception of Bawean deer (Axis kuhlii) and wildlife reserve area. Further, that also impacts on existence and sustainability of forest ecosystem directly or indirectly. Most of the citizens deliver positive attitude to forests because they have had a lot of brief and counselling from NRCA and some related agencies. Therefore, Bawean citizens learned that forests co-supply life source.

\section{Acknowledgement}

The author would like thanks to Mr Sudirman who had helped in accommodation; District Chief of Tambak and Sangkapura, Region of Gresik; Mr Nur Samsi (Head of Natural Resource Conservation Agency (NRCA) of Bawean Island) for permitting the author to conduct the study. The author sincerely thanks Prof. Suyadi, Dr Moch. Sasmito Djati and Dr Bagyo Yanuwiadi, who guide and brief the author during the study.

\section{Ethics}

The author declares that there are no ethical issues related to this study.

\section{References}

Barlow, L.A., J. Cecile, C.T. Bauch and M. Anand, 2014. Modelling interaction between forest pest invasion and human decisions regarding firewood transport restrictions. PLoS ONE, 9: e90511-e90511. DOI: 10.1371\%2Fjournal.pone.0090511

Bedural, Z.L., 2018. Association between educational attainment and filipinos' values, attitudes and actions towards the environment. JSEDR, 2: 59-67. DOI: 10/12359-25811-1-SM 
Bobo, K.S., F.F.M. Aghomo and B.C. Ntumwel, 2015 Wildlife use and role of taboos in the conservation of wildlife around the Nkwende hills forest reserve: South-West Cameroon. J. Ethnobiol. Ethnomed., 11: 2-2. DOI: $10.1186 \% 2 F 1746-4269-11-2$

Byrd, E., J.G. Lee and N.J.O. Widmar, 2017. Perceptions of hunting and hunters by U.S. respondents. Animals (Basel), 7: 83-83. DOI: $10.3390 \% 2$ Fani7110083

Doonan, G., M. Appelt and C. Inch, 2009. Role of legislation in support of animal welfare. Can. Vet. J., 50: 233-234. PMID: 19436475

Elmaleh, A., J.P. Valet, X. Quidelleur, A. Solihin and H. Bouquerel et al., 2007. Palaeosecular variation in Java and Bawean Islands (Indonesia) during the Brunhes chron. Geophys. J. Int., 157: 441-454. DOI: 10.1111/j.1365-246X.2004.02197.x

Kennedy, C.A., I. Stewart, A. Facchini, I. Cersosimo and R. Mele et al., 2015. Energy and material flow of megacities. Proc. Natl. Soc. Am., 112: 5985-5990. DOI: $10.1073 /$ pnas.1504315112

Lieflander, A.K. and F.X. Bogner, 2018. Educational impact on the relationship of environmental knowledge and attitude. Environ. Educ. Res., 24: 611-624. DOI: 10.1080/13504622.2016.1188265

Nurcahyo, W., 2015. Monitoring of physiological and parasites status of Bawean deer (Axis kuhlii) in its habitat as a baseline for wildlife conservation endeavor. JSV, 33: 126-133. DOI: $10.22146 /$ jsv. 22001

Prevedello, J.A., C.R. Dickman, M.V. Vieira and I.M. Vieira, 2013. Population responses of small mammals to food supply and predators: A global meta-analysis. J. Anim. Ecol., 82: 927-936.

DOI: 10.1111/1365-2656.12072

Rademaker, M., E. Meijaard, G. Semiadi, S. Blokland and E.W. Neilson et al., 2016. First ecological study of Bawean warty pig (Sus blouchi), one of the rarest pigs on earth. PLoS ONE, 11: e0151732-e0151732. DOI: 10.1371/journal.pone.0151732
Rahman, D.A., G. Gonzalez and S. Aulagnier, 2017a. Population size, distribution and status of the remote and critically endangered Bawean deer Axis kuhlii. Oryx, 51: 665-672. DOI: $10.1017 / \mathrm{S} 0030605316000429$

Rahman, D.A., G. Gonzalez and S. Aulagnier, 2016. Benefit of camera trapping for surveying the critically endangered Bawean deer Axis kuhlii (Temminck, 1836). Trop. Zool., 29: 155-172. DOI: 10.1080/03946975.2016.1199763

Rahman, D.A., G. Gonzalez, M. Haryono, A. Muhtarom and A.Y. Firdaus et al., 2017b. Factors affecting seasonal habitat use and predicted range of two topical deer in Indonesian rainforest. Acta. Oecol., 82: 41-51. DOI: 10.1016/j.actao.2017.05.008

Rode-Margono, E.J., H. Khwaja, M. Rademaker and G. Semiadi, 2019. Ecology and conservation of the endemic Bawean warty pig Sus verrucosus and Bawean deer Axis kuhlii. Oryx. DOI: 10.1017/S0030605318000996

Saito, M. and F. Koike, 2013. Distribution of wild mammals assemblages along an urban-rural-forest landscape gradient in warm-temperate East Asia. PLoS ONE, 8: e65464-e65464.

DOI: $10.1371 \%$ 2Fjournal.pone.0065464

Semiadi, G., S. Pudyatmoko, J.W. Duckworth and R.J. Timmins, 2008. Axis kuhlii. the IUCN red list of threatened species.

Semiadi, G., K. Subekti, I.K. Sutama, B. Masy'ud and L. Affandy, 2003. Antler's growth of the endangered and endemic Bawean deer (Axis kuhlii Muller and Schlegel, 1842). Treubia, 33: 89-95.

Sorqvist, P., 2016. Grand challenges in environmental psychology. Front. Psychol., 7: 583-583.

DOI: $10.3389 \% 2 F f p s y g .2016 .00583$

Symes, W.S., D.P. Edwards, J. Miettinen, F.E. Rheindt and L.R. Carrasco, 2018. Combined impacts of deforestation and wildlife trade on biodiversity are severely underestimated. Nat. Commun., 9: 4052-4052.

DOI: $10.1038 \% 2 F s 41467-018-06579-2$ 